\section{Multidisciplinary SCIENTIFIC JOURNAL OF MARITIME RESEARCH}

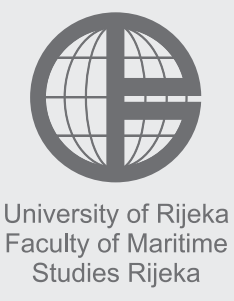

\author{
Multidisciplinarni \\ znanstveni časopis \\ POMORSTVO
}

\title{
Quality of maritime higher education from seafarers' perspective
}

\author{
Leo Čampara ${ }^{1}$, Vlado Frančić ${ }^{2}$, Matko Bupić ${ }^{3}$ \\ ${ }^{1}$ University of Dubrovnik, Maritime Department, Ćira Carića 4, 20000 Dubrovnik, e-mail: leo.campara@unidu.hr \\ ${ }^{2}$ University of Rijeka, Faculty of Maritime Studies Rijeka, Studentska 2,51000 Rijeka, e-mail: vfrancic@pfri.hr \\ ${ }^{4}$ University of Dubrovnik, Maritime Department, Ćira Carića 4, 20000 Dubrovnik, e-mail: matko.bupic@unidu.hr
}

\begin{abstract}
The quality of maritime education system could be considered as one of the most important pillar for safe and efficient shipping. Particularly vital is the maritime education at the university level and those ensuring seafarers' top rank qualifications in accordance with the STCW Convention. Generally, the quality of education of the individuals is correlated to the employability and promotion opportunities. In Croatia, maritime education system is well established with a long tradition of education at the university level enabling acquisition of top rank seafarers' qualifications. This paper presents a survey of the results related to the seafarers' satisfaction with the quality of maritime education and curricula provided during their education at the maritime higher education institution in Dubrovnik. The research was carried out by interviewing 154 marine engineers with different sea service experience, educational level and rank aiming to obtain their opinions about importance, correlation and connectivity of education to their professional career.
\end{abstract}

\section{ARTICLE IN FO}

Preliminary communication Received 15 November 2017

Accepted 18 December 2017

\section{Key words:}

Quality of maritime education in Croatia Maritime higher education institutions Marine engineer's education Special education programme Importance of seafarers' education

\section{Introduction}

Safe and efficient ship management is not possible without well trained and motivated seafarers. Croatia is a traditionally maritime country with educated, professional, responsible and reliable seafarers that are recognizable as a brand, respected and wanted at the global market. Today in Croatia, with a population of about 4,5 mil., there are about 22,000 seafarers of whom about 14,500 are serving on board ships engaged in international voyages and whose irrefutable number is a significant contributor to the country's economic prosperity [16].

Over the past fifteen years in the European Union countries (EU), a diminished interest for seafaring professions has been noticed. Although demand in the EU, especially for officers, is growing there is an acute shortage of qualified seafarers on the labour market. In 2002, the EU merchant fleet had a deficit of about 30,000 trained officers, representing a deficit of around 30\% [11]. As early as 2001, the European Commission in its communication on seafarers' training and employment has highlighted this growing problem and has proposed a series of meas- ures to reverse the negative trend of seafarers' shortages. Among other things, they stimulated the national maritime education systems to establish the best possible seafaring education system while raising awareness and image of maritime careers in order to attract young people to start a seafaring career. That is the reason, along with the lines of the Strategy for Maritime Development and Integral Maritime Policy for the 2014-2020 period. which coincides with the EU Strategy, why Croatia has a mission to develop and promote itself as an International Centre for Excellence for maritime education and training (MET) and to continuously improve the quality of the MET system, providing a highly educated, socially and health cared seafarers, capable of responding to the requirements of modern shipping, as well as providing conditions for the shore-based seafarers' employment after they finish their sea career [16].

Over the last twenty years, the European and global maritime higher education institutions (MHEI), as well as other stakeholders in shipping, are intensifying their activities in research collaboration aiming to establish and 
standardize MET programmes as well as teaching materials. Their ultimate goals, in the most general sense, is to improve the quality of MET and to implement modern information technologies (IT) in education and training with the purpose of providing competitive seafarers for the labour market, popularization of seafarer professions and enabling seafarers' shore-based employment.

In this article, a survey deals with active marine engineers who have acquired their maritime education at the Dubrovnik higher education institutions. The survey has been conducted among 154 marine engineers serving on board merchant ships engaged in international voyages with the intention to determine their opinion about the quality of MET provided during their higher education, compliance of curricula and teaching materials with the needs of modern shipping and finally, the impact of the acquired knowledge to competitiveness in their promotion comparing to seafarers of other nationalities educated on different MHEIs.

\section{Particulars and structure of the maritime higher education process}

The fundamental task of MET is seafarers' education in a way that they acquire applicable knowledge, skills and competences in accordance with the techniques and technologies required for the modern on board ship management but also to be prepared for the development of global shipping as a whole.

The basis of MET was defined in the STCW ${ }^{1}$ Convention. In addition, the IMO Model Courses ${ }^{2}$ provided guides for the application of specific training programmes. The content of the model courses, over the years, has continuously been harmonised by following the new standards of competences required by the STCW Convention, most notably in terms of standards related to safety at sea, marine environment protection, and the English language with maritime terminology. An important influential factor on the MET system is the accelerated technological advancement in the maritime industry, which necessarily requires better educated, trained and competitive seafarers that can deal with increasingly demanding and complex ship management. Therefore, it is necessary to continuously update and upgrade the MET educational contents, but more effective and proactive affirmation of educated and experienced lecturers as well $[4,5,15]$.

In the last decades, the EU fleet has faced with the shortage of seafarers, especially the officers. The lack of interest for maritime professions and the influx of more

\footnotetext{
STCW Convention - International Convention on Standards of Training, Certification and Watch keeping for Seafarers from 1978. as amended; has been ratified by 162 states so far.

2 IMO model courses include a list of topics that need to be addressed within a specific education and training programme for each individual qualification certificate and the number of teaching hours to be spent on each of these topics. The contents of the IMO model courses should be used as a guide and can be modified to suit respective training schemes of the MET institution.
}

competitive labour force from the Far East countries have been identified as the main reasons. This cognition urged the EU to adopt a strategy to promote but also to sponsor numerous regional and international researches in the area of MET through multi-annual funding programmes ${ }^{3}$ in order to mitigate the negative trends and ultimately terminate it. Likewise, European and global MET institutions are pooled into different platforms and associations so that they could, with support of concentrated intellectual, experimental and other resources through a variety of researches, studies, analysis and with support of the mentioned EU funding programmes, be able to offer with some insights to increase MET standards and thus achieve the ultimate goals, more accessible MET and a high quality, modern and at global level competitive European merchant fleet as well as an increased attractiveness of the maritime profession among young people in the EU [19, 20, 21].

The Croatian centenary maritime tradition has shaped the foundation and development of maritime education institutions in numerous Adriatic coastal cities that have systematically and successfully followed and implemented international trends in the MET development, as well as progress and the modernization of marine technologies. Therefore, Croatia nowadays has eight active secondary schools with nautical and/or marine engineering education programmes as well as four MHEI delivering both study programmes.

The particularity of seafarers' education is manifested through two concepts that are typical for all qualifications and is defined in the Ordinance on Seafarers' Qualifications and Certifications (Ordinance). Education, which means acquiring knowledge and skills within regular education and Training, which means acquiring knowledge and skills through the specialized training courses and by lifelong learning concept [13].

In Croatia, education for acquiring the highest marine engineer's qualifications is implemented at the MHEI through a regular programme of undergraduate studies or through a seafarers' Special Education Programme (SEP).

\subsection{Maritime higher education}

The existing system of higher education at the MHEIs has been launched in 2005. It is harmonized with the provisions of the Bologna Declaration, which resulted in the division of university studies into three levels: undergraduate, graduate and postgraduate studies. This is a precondition for the inclusion of Croatian university studies into the European higher education system, which is mostly

\footnotetext{
EU financial programmes are funding instruments covering all scientific disciplines with strategic goal to strengthen the scientific and technological capacities of the European industry and to foster international competition by facilitating joint research that supports EU policy. Some of the most significant instruments include: EU RTD framework programmes, EU Leonardo Transfer of Innovation Programme, EU Leonardo Pilot Programme, EU Leonardo Mobility Programme, EU Leonardo Lifelong Learning Programme, EU Erasmus +, Strategic Partnership for VET, ...
} 
reflected in the ability of undergraduate students to continue studying on EU universities with similar curricula [2, 18].

Undergraduate study at MHEI lasts for three years and by graduation credits students are awarded with 180 ECTS and a bachelor degree (bacc. - baccalaureus) in marine engineering or nautical sciences. In addition to those who have completed maritime secondary school, undergraduate studies can be enrolled by students who completed other secondary schools, subjected to passing additional programmes meeting the STCW requirement for STCW content. Until recently, undergraduate study was specific because it was divided into $2+1$ year. Namely, all content programmes subjected to the STCW Convention for obtaining qualification were deployed within the first two years of study. Thus, after the second year of study, students could terminate the study and request a confirmation that they have completed first two years of undergraduate study meeting all STCW requirements for obtaining highest qualifications, namely Second Engine Officer (SEO)/Chief Engineer (CE) and Chief Officer (CO)/Master Mariner (MM). From the academic year 2013/2014, the courses with mandatory STCW contents were deployed through all three years of undergraduate studies and one year later this was done at the Department of Maritime Studies at the University of Dubrovnik as well [10].

Graduate university study can be enrolled by students who have previously completed undergraduate studies of nautical or marine engineering programmes. Upon completion of two years graduate study, students obtain the 120 ETCS and an academic master's degree. With a total of 300 ETCS, if the maritime higher education system compares with the METNET ${ }^{4}$ classification, it can be said then that it represents the $4 \mathrm{E}$ level of education that the Croatian maritime higher education system makes comparable to similar EU studies. The aim of the graduate study is to offer education enabling graduates to perform the most complex shore-based maritime related jobs at management level in ports, maritime agencies and shipping, both in Croatia and at the international market. In addition to maritime industry, the study programme can be applicable in many branches of economy and in various scientific areas, which also provide fundaments for a more successful development of private enterprise $[6,7$, 10].

\footnotetext{
4 METNET - The Thematic Network on Maritime Education, Training and Mobility of Seafarers is one of the most significant projects aimed to find and exploit the ways and resources to make better use of education and training of ship officers in order to slow down and ultimately stop the negative tendency for maritime professions interests in the EU. The essence of this goal is the sustainability of competent and competitive maritime services and maritime skills within the EU, especially because education, training and navigation experience of ships' officers is important and necessary in the maritime sector ashore. The most important project results can be presented through the three most significant outcomes: 4E concept of education classification, development of common curricula and design of programmes and courses needed for MET expansion and enrichment.
}

It should be emphasized that, in addition to mandatory, a certain number of elective courses are offered to students during both, undergraduate and graduate study.

Since 2006, at the Faculty of Maritime Studies in Rijeka an integrated postgraduate doctoral study "Maritime Affairs" with an academic title of Doctor of Sciences (Ph.D.) in the field of traffic and transportation technology has been offered. The main goal of the study is to provide students with effective education through the teaching and research elements, extending their knowledge and deepening their expertise through original scientific research that meets internationally accepted standards of quality and contributes significantly to the development of science within the maritime industry [14].

\subsection{Special educational programme}

In an alternative to the presented maritime higher education system in Croatia, in 2011, the Special Education Programme was introduced. It followed as a response to the demands for enabling Croatian seafarers to acquire SEO/CE or CO/MM STCW qualification without the completion of maritime higher education, as it is possible in some countries around the world, all in accordance with the STCW Convention. The advantage of this programme is a relatively short duration and a certain degree of flexibility as compared to a standard education system. The system provides seafarers to actively continue with a sea service with the shipping company while attending the education programme parallel with. SEP is intended to experienced seafarers as a part of lifelong learning system. The conditions for the admission to the SEP are maritime secondary school diploma and more than 36 months of sea service as a deck/marine engineering officer [3].

MHEIs are the only education institutions allowed to carry out SEP. At the Maritime department of the University of Dubrovnik, SEP lasts for 6 months (14 weeks) in total. It is divided into two parts with a total number of 795 lecture hours that are prescribed by the Ordinance. The SEP system is conceived as a lifelong learning system, and the students/seafarers achieve 79 for marine engineering and 76 ETCS for nautical programme. Upon completing the SEP, certificates of completion are issued based on which, passing examination organised by the maritime authority (harbour master office) and with the corresponding sea service time, the seafarers can obtained STCW Certificates of Competence for CEO/CE or CO/MM. SEP does not make available participants to obtain an academic degree $[3,9,13]$.

The following figure presents the process of acquiring the STCW qualifications through an example for marine engineering officers in Croatia according to the current MET system, as well as the possibilities of further education in progress and after the completion of the sea career. The same system applies to nautical officers. 


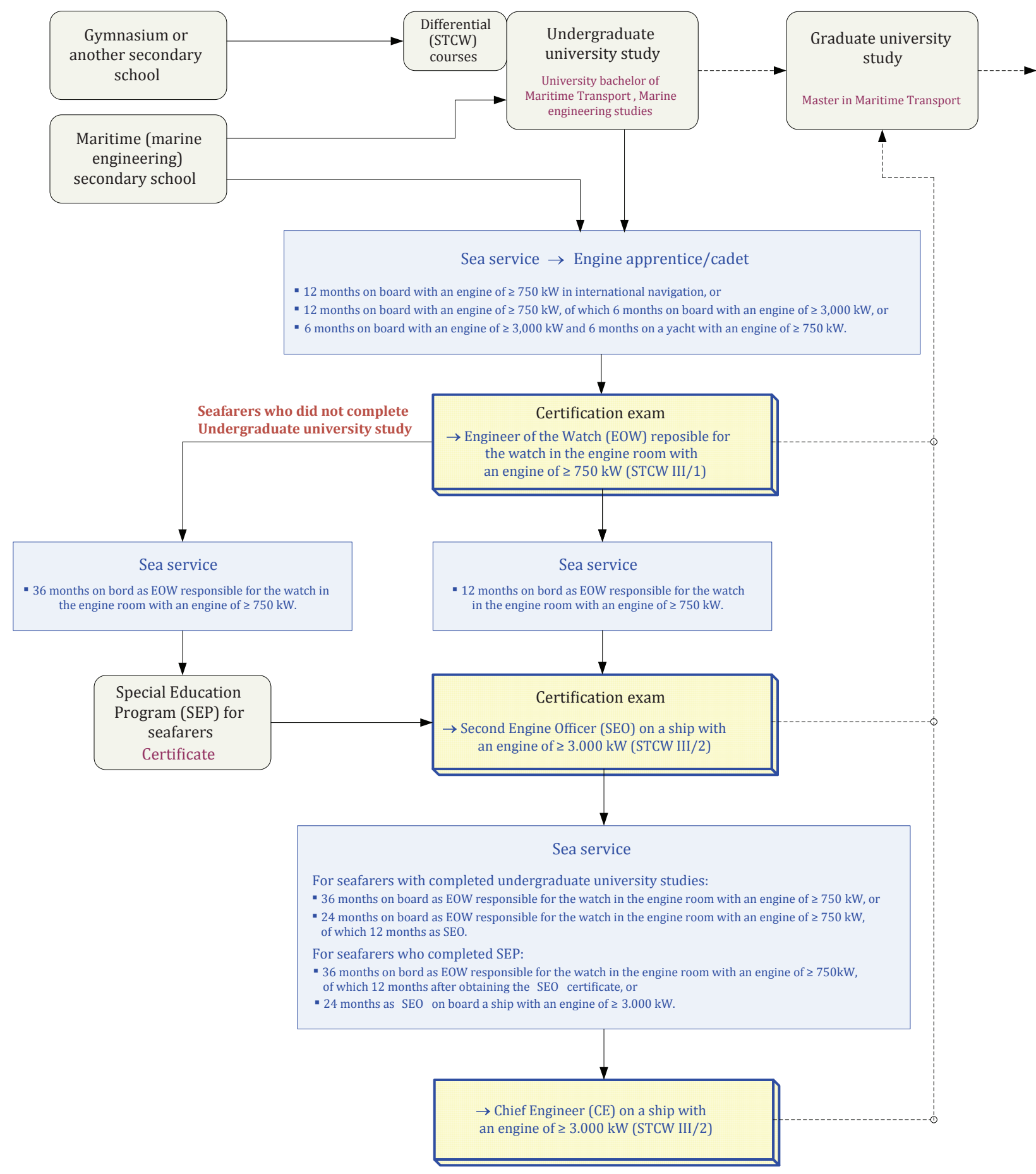

Figure 1 Organisation of Croatian MET and STCW Certification System for Marine Engineers. Source: Author

\section{Analysis of MET programmes, teaching staff and students}

A quantitative and qualitative analysis of the MET programme, conducted in the recently completed Croatian project KIKLOP ${ }^{5}$, which the Faculty of Maritime Studies from Rijeka and Split took part in among other contribu-

5 KIKLOP - Development of Qualification and Innovative Methods of Acquisition Competence in Logistics and Maritime Traffic is a project tors from the maritime industry, has stated that maritime education is a multidisciplinary scientific area based on activities with different technical and technological as well as economic and legal features. Therefore, providers of maritime higher education in Croatia, scientific but also MHEIs, must continually adapt their educational pro-

funded by the European Social Fund (ESF) - Operational Program "Human Resources Development" 2007-2013. 
grammes to the needs of the national and international shipping labour markets, while at the same time to be recognizable in the European Higher Education Area (EHEA) and harmonized with all requirements of the national educational system, STCW Convention and other relevant international regulations [11].

Although, the programmes prepared and delivered by individual MHEI have been adapting to internal and external requirements according to the principles of the Bologna Declaration, significant objectives as well as subjective shortcomings are notable. Study programmes are often tailored to the capabilities and availabilities of the teaching staff without consultation with other stakeholders (employers, different state institutions and bodies, etc.) and without analysing the actual labour market needs. For that reason, the current analysis of demands for particular profession indicates the necessity of an adaptation of the programme structure and learning outcomes, qualifications, as well as how the programme needs are to be performed within the framework of a particular curriculum [11].

However, despite the above mentioned factors that have affect in improvement and modernization of MET in general, the disparity in the programme content of undergraduate studies on MHEIs is observed. This is manifested in the diversity of subject titles, hours of lessons and number of attached ECTS for STCW related courses, but also for those that are considered as general subjects. A different order of delivering courses within three years of undergraduate studies has been noticed as well. Particularly surprising is the fact that some equivalent courses, with the same title and with identical attached number of hours have been assigned a different value of ECTS credits. In Table 1, a comparison of the above-mentioned differences is clearly presented.

These differences came to the fore during the last revision of the MHEIs programmes, as MHEIs retained the right to create their own education study programmes in accordance with all relevant regulations, despite of the fact that at the time of aligning with the Bologna Reform, all MHEIs representative working groups supported by the government and having as their objectives the adaptation, alignment and development of equal programme contents, has been established.

In the article [1], the status of the MET system in Croatia regarding the current trends and challenges and with special emphasis on the impact of the SEP introduced at the existing MET system has been analysed. The authors of the article have pointed out SEP as a possible threat to the quality of education of seafarers due to decreasing educational standards. The paper presents a SWOT analysis of the most prominent characteristics and challenges that

Table 1 Comparison of Croatian MHEIs Courses

\begin{tabular}{|c|c|c|c|c|c|c|c|c|c|c|c|}
\hline \multicolumn{3}{|c|}{$\begin{array}{c}\text { Faculty of Maritime Studies, } \\
\text { University of Rijeka }\end{array}$} & \multicolumn{3}{|c|}{$\begin{array}{c}\text { Faculty of Maritime Studies, } \\
\text { University of Split }\end{array}$} & \multicolumn{3}{|c|}{$\begin{array}{l}\text { Maritime Department, } \\
\text { University of Dubrovnik }\end{array}$} & \multicolumn{3}{|c|}{$\begin{array}{l}\text { Maritime Department, } \\
\text { University of Zadar }\end{array}$} \\
\hline Semester & $\begin{array}{c}\text { Hours/week } \\
\mathrm{L}^{*}+\mathrm{E}^{* *}\end{array}$ & ECTS & Semester & $\begin{array}{c}\text { Hours/week } \\
\text { L+E }\end{array}$ & ECTS & Semester & $\begin{array}{c}\text { Hours/week } \\
\text { L+E }\end{array}$ & ECTS & Semester & $\begin{array}{c}\text { Hours/week } \\
\text { L+E }\end{array}$ & ECTS \\
\hline \multicolumn{3}{|c|}{ Marine engines } & \multicolumn{3}{|c|}{ Marine engines } & \multicolumn{3}{|c|}{ Marine engines } & \multicolumn{3}{|c|}{ Marine engines } \\
\hline IV & $4+1$ & 7 & IV & $4+2$ & 7 & IV & $4+2$ & 6 & IV & $4+1$ & 6 \\
\hline \multicolumn{3}{|c|}{ Maritime law } & \multicolumn{3}{|c|}{ Maritime law and accidents } & \multicolumn{3}{|c|}{ Maritime law and accidents } & \multicolumn{3}{|c|}{ Maritime law } \\
\hline \multicolumn{3}{|c|}{ Marine heat turbines } & \multicolumn{3}{|c|}{$\begin{array}{l}\text { Marine steam generators and } \\
\text { heat turbines }\end{array}$} & \multicolumn{3}{|c|}{ Marine heat turbines } & \multicolumn{3}{|c|}{ Marine steam and gas turbines } \\
\hline IV & $2+1$ & 4 & III & $4+1$ & 5 & $\mathrm{~V}$ & $2+1$ & 4 & IV & $2+1$ & 4 \\
\hline \multicolumn{3}{|c|}{ 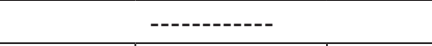 } & \multicolumn{3}{|c|}{ Ship construction } & \multicolumn{3}{|c|}{ Ship construction } & \multicolumn{3}{|c|}{ Ship construction and stability } \\
\hline--- & --- & --- & III & $2+1$ & 4 & III & $2+1$ & 4 & III & $4+2$ & 6 \\
\hline \multicolumn{3}{|c|}{ Marine environment protection } & \multicolumn{3}{|c|}{$\begin{array}{l}\text { The sea and the marine } \\
\text { environment protection }\end{array}$} & \multicolumn{3}{|c|}{$\begin{array}{l}\text { The sea and the marine } \\
\text { environment protection }\end{array}$} & \multicolumn{3}{|c|}{$\begin{array}{l}\text { The sea and the marine } \\
\text { environment protection }\end{array}$} \\
\hline IV & $2+0$ & 3 & $\mathrm{~V}$ & $2+0$ & 2 & III & $2+0$ & 3 & II & $2+0$ & 3 \\
\hline \multicolumn{3}{|c|}{ Safety at sea } & \multicolumn{3}{|c|}{ Safety at sea } & \multicolumn{3}{|c|}{ Safety at sea } & \multicolumn{3}{|c|}{ Safety at sea } \\
\hline IV & $3+1$ & 4 & IV & $3+1$ & 4 & II & $2+1$ & 4 & III & $3+1$ & 5 \\
\hline \multicolumn{3}{|c|}{ English language I } & Eng & lish language & & En & ish language I & & & lish language I & \\
\hline $\mathrm{I}$ & $1+2$ & 4 & I & $1+2$ & 3 & I & $2+1$ & 3 & I & $1+2$ & 4 \\
\hline Eng & lish language I & & Eng & lish language I & & Eng & sh language I & & En & lish language II & \\
\hline II & $1+2$ & 3 & II & $1+2$ & 3 & II & $2+1$ & 3 & II & $1+2$ & 4 \\
\hline
\end{tabular}

*Lectures; **Exercises 
the Croatian MET system has been faced with at the time of writing it and in the future. As the most important advantages of the Croatian MET system, the following have been selected: longstanding tradition and good organization, established system of maritime higher education with degrees (BSc, MSc, PhD), preparation of students for shore-based employment, while shortcomings have been pointed out as a decrease in educational standards by introducing SEP, (pre)frequent programme changes, shortage of seafarers/students and theoretically oriented teaching staff [18].

By comparing some of the items of the mentioned SWOT analysis with the current situation at the Maritime Department of the University of Dubrovnik, it can be concluded that SEP does not significantly affect the quality of the parallel university MET system. The number of students has been increased in recent years due to the growing interest for maritime professions, especially from the academic year 2009/2010 (Figure 2). Participants of the SEP include mostly experienced seafarers who have taken the advantage of an alternative system to obtain the required qualifications. Because of the small interest of students to quit the study after the second year of undergraduate studies, from the 2014/2015 academic year on, the courses with the required STCW contents have been distributed within the three-year study programme. If the SWOT analysis takes into account the concern of the academic community in maritime education that educational standards could be reduced by introducing SEP, then, with the lack of interest of the today's two-year study programme students, with the revision of the undergraduate study programmes and with the redistribution of the STCW based courses through all three years of study, could be understood as the maintenance of the MET system high standards and quality in Croatia.

Employing deck and engine cadets holding the maritime secondary school diploma is relatively low nowadays. The vast majority of employers prefer cadets graduated from MHEIs as they are considered as more valuable and better employees, specifically in term of possible promotion. Shipping companies commonly establish long-term goals that, with additional investment in specialized training and incentives based on competitive salaries with various bonuses and retirement insurance packages, they will be able to attract well educated and highly professional and satisfied seafarers/officers. Therefore, most secondary school graduates decide to continue their education at the MHEI. In addition, it is important to point out that presently and after graduation from a maritime high school, employment as cadet is not easy to find. This is one of the most serious problems that are not directly connected to the quality of the MET system. Nevertheless, along with other stakeholders from maritime industry and the support of the government, a solution to enable all, or at least the majority of graduate students to have a guaranteed first employment should be found. This can be achieved with additional efforts of all stakeholders and, particularly, through the creation of mutually beneficial partnerships between shipping companies and the MHEIs.

The lack of a teaching staff with appropriate STCW qualifications is a challenge faced by the Maritime Department of the University of Dubrovnik, as well as by other MHEIs. The aforementioned facts often result in the overload of individual teachers and in their reduced quality of teaching. The necessary training of the existing teaching staff for the application of new "student-centred" standards in education, set up and required by qualification frameworks, should be added. This implies a relatively new approach to the education process, focusing on students and their individual achievements and in the practice applicable skills. The traditional delivery of prescribed programme contents with large amounts of data, with the teacher in the main role, should become less important. The focus of the new concept is on the quality and not on the quantity of learning [21].

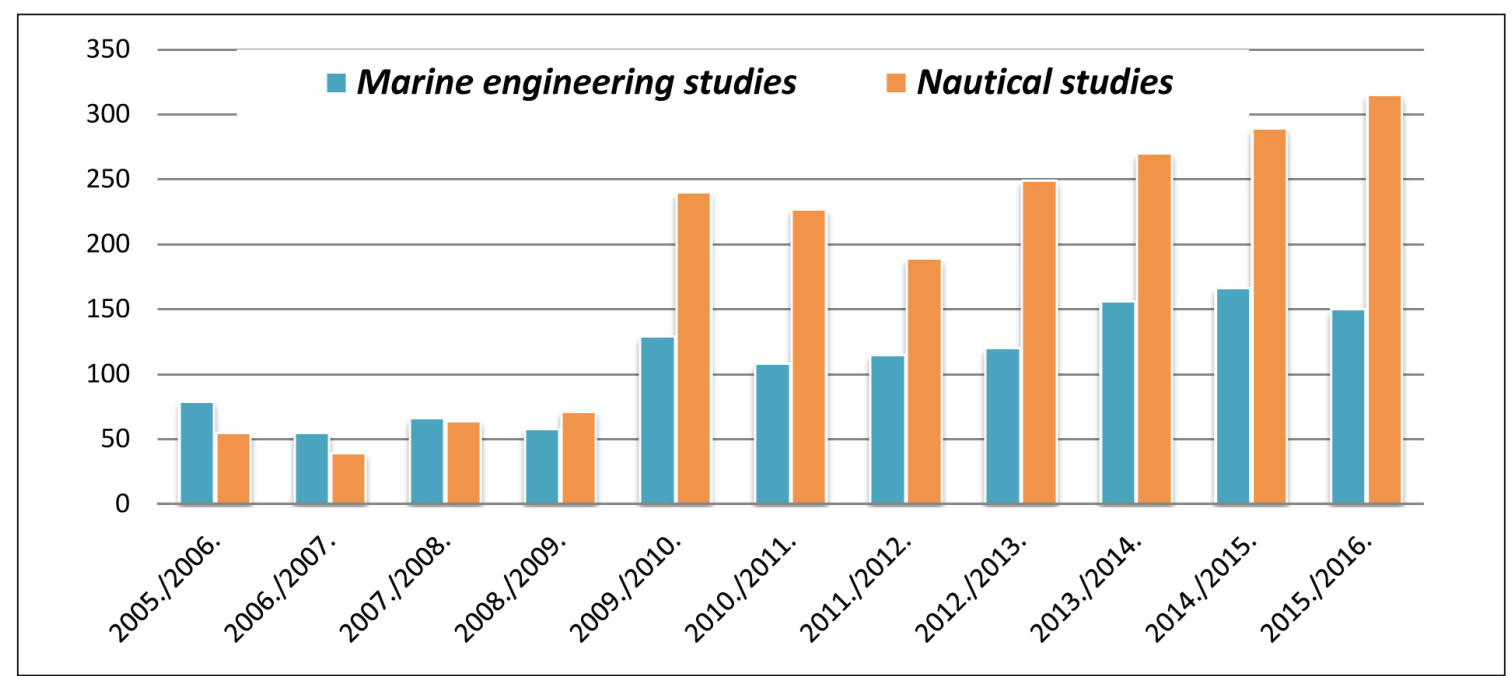

Figure 2 Number of Applicants Enrolled in the First Year of Maritime Studies at the Maritime Department of the University of Dubrovnik 
Although many seafarers, after a certain time on board, tend to continue with shore-based career, only few are those who are attracted to work as a teacher at the MHEI with mandatory further scientific advancement. One of the main reasons for this is also the incomparable difference in salaries, as well as lack of interest for further postgraduate education and continuous scientific and research work, which is a necessary precondition for a teacher at the MHEI.

\section{Evaluation of educational programmes at the MHEI}

Croatian higher maritime education has generated a large number of seafarers and, therefore, their deliberation and judgment are relevant in assessing the quality of the MHEIs performance. For this purpose, a survey has been carried out among the sample of 154 active marine engineers who have obtained their maritime education at the Dubrovnik maritime education institutions. The aim of the research is to determine the satisfaction of seafarers regarding the curriculum contents and quality of education at the MHEI, as well as the usefulness and applicability of the acquired knowledge and skills in their maritime careers.

The basic hypothesis of the research is that the active marine engineers are generally satisfied with the quality of education and curricula provided at the MHEI in Dubrovnik.

In order to analyse the survey results clearly enough, the research questionnaire begins with general questions that define and analyse the basic characteristics of the survey respondents and include: age, years of sea service, qualification certificate, maritime educational degree, year of graduation, current position on board the ship and type of ship they currently work on.

The survey questions are generally related to the evaluation of maritime education at all levels of the educational process, particularly at the university level. The questions aimed to determine the seafarers' opinion on the importance of vocational/technical courses and their content, their place in comparison to the so-called general education subjects and the importance of practical training and its relationship with theoretical teaching. Presuming that seafarers with a higher education, as well as those holding a higher certificate of competence level or on board rank are more aware of the importance of education, the analysis has included two levels defined by supplementary hypotheses:

- seafarers who have obtained a higher level of education are more aware of the importance of education and are more satisfied with the acquired knowledge during education,

- seafarers who have obtained a higher competence/ rank at the management positions and a longer working experience are more aware of the importance of education and are more satisfied with the acquired knowledge during education.
Considering the above mentioned questions related to theoretical education, it was interesting to determine the respondents' opinions regarding relation and coupling of theoretical and practical knowledge for their career.

The survey is followed by a question regarding the five, in the seafarers' opinion, most important vocational/ technical courses, completed during higher education and which they consider useful for the shipboard work and for their career in general and by the one suggesting which of the vocational/technical courses are not included in the study programme, but, considering their work experience, should be included in the curricula.

English speaking skills and maritime English terminology are crucial for mutual communications, efficient and safe work, as well as for the socialization of the ship's crew. The IT modernization of ships and the application of various computers and software for different purposes require a high level of IT knowledge for today's seafarers. Given the immense importance of these two elements in modern shipping, it was equally important to determine the seafarers opinions about these issues. Therefore, from the author's perspective, it has been logical to assume additional supplementary hypotheses:

- knowledge of the English language is important for on board work and for the seafarers' career in general,

- IT knowledge is important for on board work and for seafarers' career in general.

The knowledge of leadership and human resources management in the engine room department, as well as activities of organizing and distributing jobs on board, experienced seafarers mostly acquire through working experience and by attending tailor made courses. However, given the modernization of shipping, the ever faster pace of work, the improvement in safety and efficiency of working processes on board, the need for systematic approach to this issue and the establishment of educational and training programmes on these topics have been imposed over the time. It has also been defined and conditioned by the STCW Convention, the provisions of which have been implemented by Croatia in its Ordinance and, therefore, for a number of years up to now, and at the undergraduate studies, the course entitled Work Organization and Engine Department Crew Management has been introduced.. These contents are presently included in the course entitled Plant (Machinery) Management and Crew Leadership.

Multinational crews are no longer an exception, but have become the rule. The knowledge of the English language, as the universal maritime language, is one of the most important segments of successful communication, but not the only one. More attention has been paid to the issues of multinational and thus multicultural communication in recent years. According to some researches in this area, recommendations are being made to implement the programmes for improving and establishing effective multi-cultural seafarers' cooperation in the MET systems as well and at the earliest convenience. It is, therefore, in- 


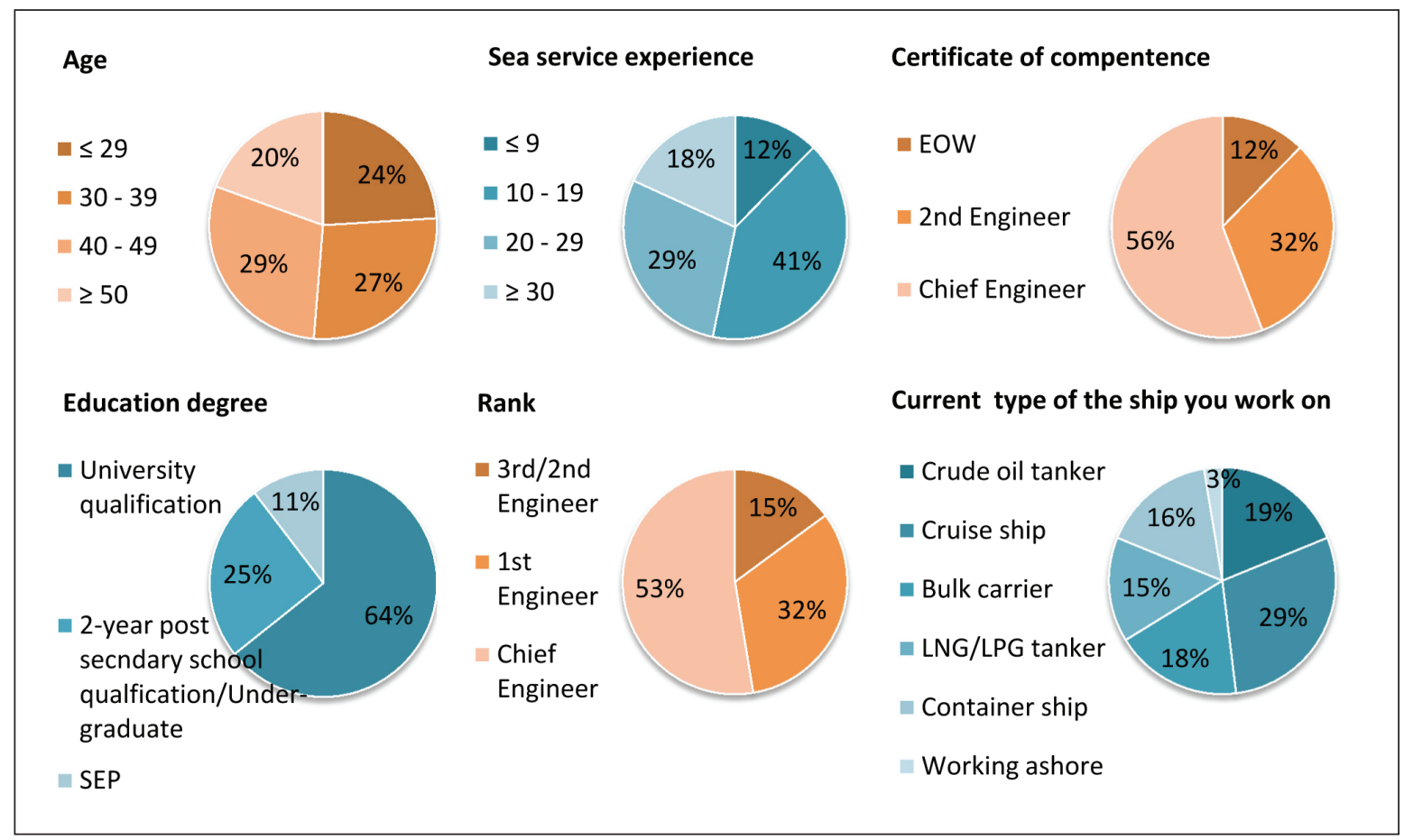

Figure 3 Basic Characteristics of the Respondents Taking Part in the Survey. Source: Author

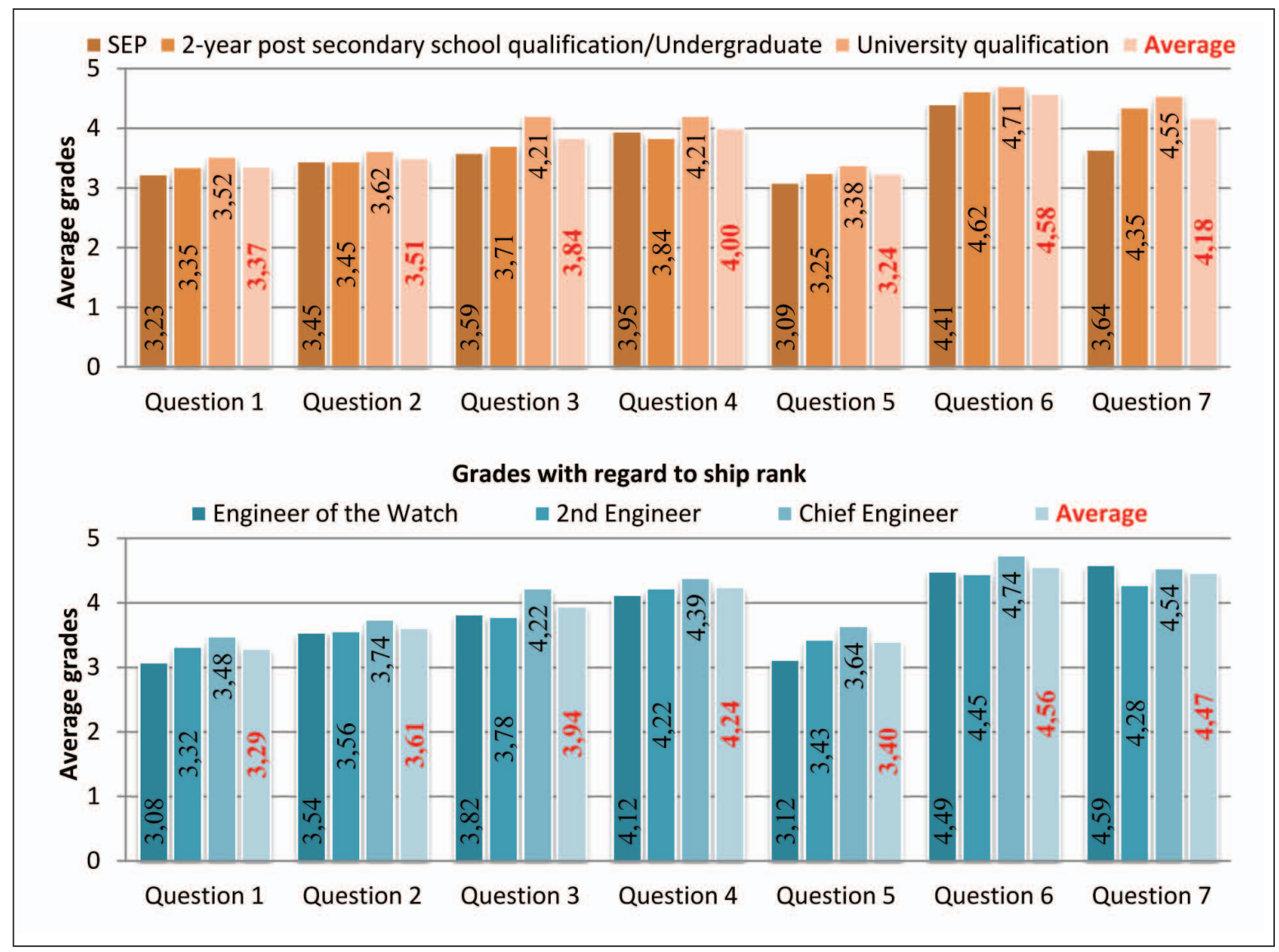

Figure 4 Comparative Overview of the Average Grades of the Assessed Questions Regarding the Degree of Education and Rank on board a Ship: 1 - Secondary school education; 2 - University education; 3 - The importance of vocational education for work on board and your career; 4 - The importance of acquiring knowledge from vocational/technical courses for on board work and your career; 5 - The importance of acquiring knowledge from general courses for work on board and your career; 6 - The importance of an internship practical education for work on board and your career; 7 - Your satisfaction with provided and acquired education and preparation for work on board with regard to labour and socialization challenges on board 
teresting to determine what active seafarers think about the importance and the most appropriate place for the preparation and training for a multicultural communication on board, with the possibility of choosing more than one answer.

The survey is concluded with several interesting questions that relate to the general opinion of the respondents on the contribution of the education quality to their competitiveness and reputation in the global maritime labour market, whether and why they consider the possibility of a further education or, on the other hand, think of ending their maritime career.

An overview of the basic characteristics of the respondents is shown in the charts in Figure 3. Given the division into four groups by age, their approximately equal percentage is apparent, while the division by the types of certificates of competence in hand and the current occupation on board the ship/rank is dominated by those with more sea experience and the highest education degree. That is, from the standpoint of the authors, what contributes to the purpose of this research since its fundamental focus is on the comprehensiveness of a complete higher education. Although, to some extent, the cruisers are ahead, it is also important to note the relative diversity of the ship types that cover the variety of the propulsion and other marine systems and machinery, which ultimately results in more comprehensive and thus better quality results of the conducted survey in respect to different technological environment, general working philosophy and the working attitude approach of marine engineers.

Figure 4 shows two comparative charts with average grades on the seven offered questions. It is visible from both charts that the lowest average grade of 3.37/3.29 has been assigned to the secondary school education, followed by a grade of $3.24 / 3.40$ on the importance of general courses for on board work and maritime career in general. On both charts, the highest average grade of 4.58/4.56 has been given to the importance of first embarkation as an engine apprentice officer/cadet. Both grades are equally followed by a high average grade of 4.18/4.47 for the question about the satisfaction of respondents with vocational and academic education as a preparation for shipboard work and with grades 4.00/4.24 for questions regarding the importance of acquiring knowledge in vocational/technical courses. Although the differences in average grades of the defined respondent groups are quite tight, they still confirm the supplementary hypothesis that the respondents with higher level of education and a higher maritime competences/rank consider education more important.

Concerning the importance of acquiring theoretical and/or practical knowledge in the education process, almost all seafarers have clearly stated that theoretical and practical education is equally important, while only two respondents opted for practical training as shown in Figure 5.

\section{The importance of theoretical and/or practical education \\ - Theoretical and practical \\ - Theoretical \\ - Practical

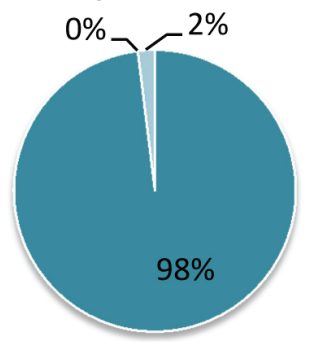

Figure 5 Importance of Theoretical and/or Practical Education for on board Work and the Seafarer's Career. Source: Author

In Figure 6, the first bar chart shows an overview of the most vocational/technical courses that seafarers have attended during higher education and which they consider useful for shipboard work as well as for their career in general. The second chart in Figure 6 shows the answers to the question on the proposal of vocational/technical courses which the institutions have not included in their curriculum, but based on the respondents' experience, it should be included in the programme. Almost two thirds of the respondents suggested more practice and practical contents, which is put under the common denominator "practical education". Bearing in mind the suggestions of the respondents, it should be noted that most of them studied when the present Maritime Department did not have a modern training equipment, including an engine room simulator, a school ship "Naše more", a marine engineering laboratory, and other teaching appliances which are presently regularly used in acquiring practical knowledge and skills. Most of other course proposals are related to the contents which have been already incorporated into the university education curriculum currently being conducted at the Maritime Department of the University of Dubrovnik.

In Figure 7 two bar charts are showing the participants' opinions on the importance of using the English language and computers application for work on board and their career in general. They also evaluated their own knowledge and practical use of the English language and IT skills on board, as well as the quality of the associated teaching contents and facilities during higher education.

All three questions related to the English language are very highly valued, while the relatively low ratings are attributed to questions of the acquired IT knowledge and skills, as well as to the quality of IT curriculum and teaching equipment. And it should be noted here as well that much has changed and improved in terms of curriculum contents, IT equipment and associated tools since the vast majority of respondents have completed their studies.

Results regarding the questions about the place of acquiring and the evaluation of knowledge regarding organization, leadership and human resources management in the engine department are shown in the charts of Figure 8. Three possible answers that can be evaluated from 1 to 5 are available as well as the option of selecting "No", if some 


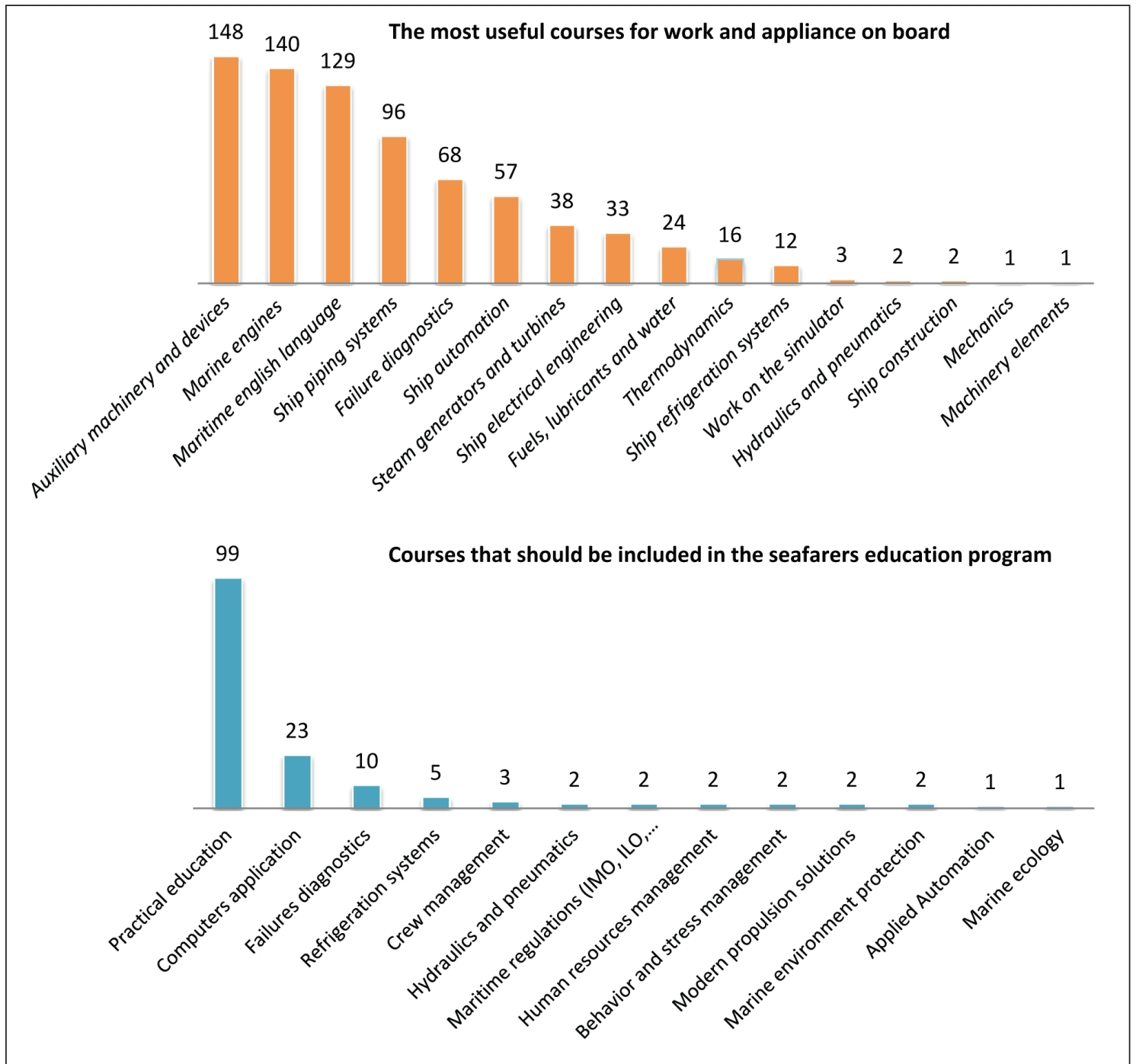

Figure 6 The Most Important Courses Attended by Respondents and the Proposal for Vocational/Technical Course that Should be Included in the Higher Educational Programmes. Source: author

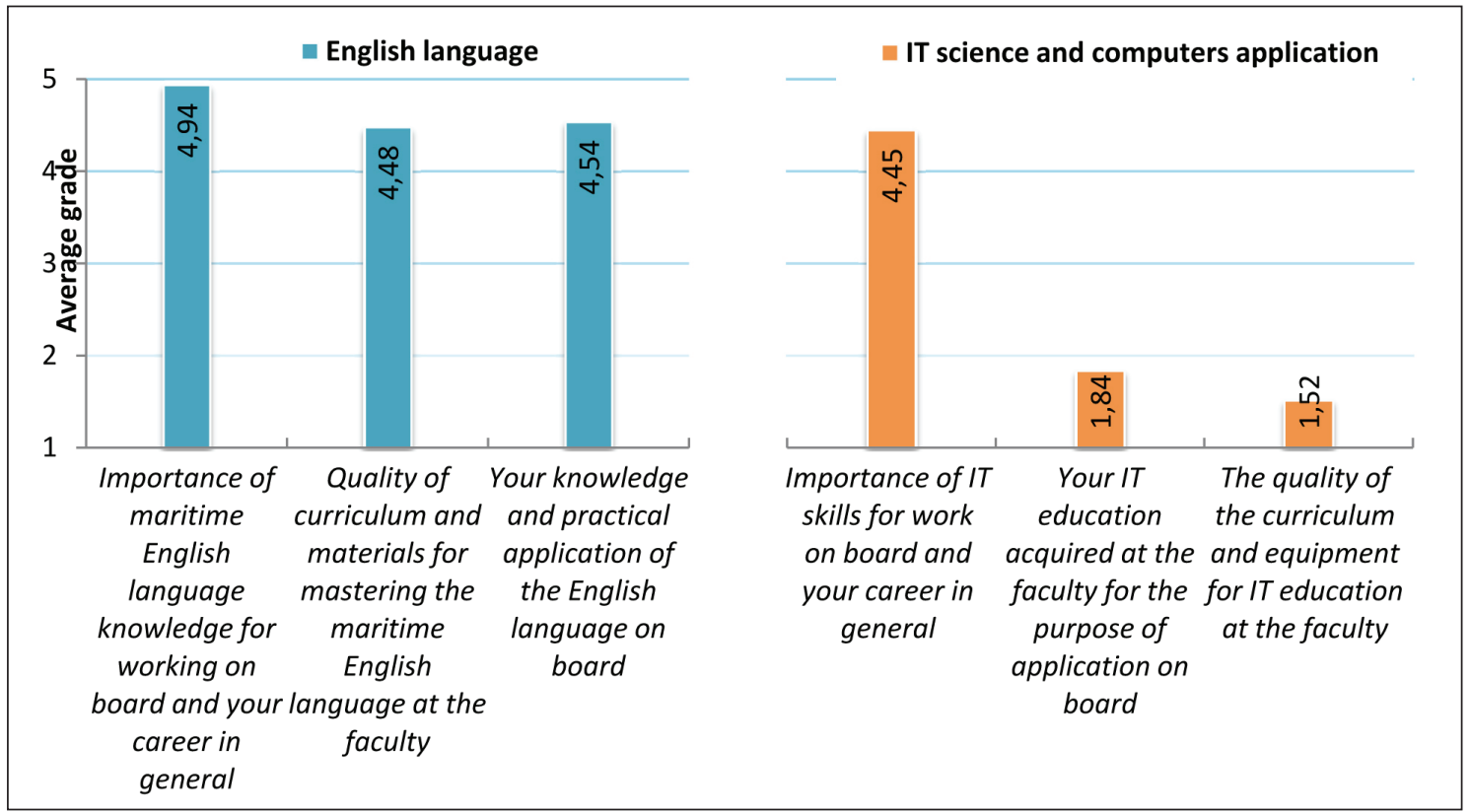

Figure 7 Opinion of the English Language, IT Science and on board Computer Application. Source: author 
of the respondents did not acquired their knowledge in one of the three offered answers. From the pie charts, it is clear that most of the knowledge on these topics the seafarers have gained at internal trainings and courses on board. Likewise, it is clearly visible that seafarers have best rated exactly those courses, while organization, leadership and human resources management, according to respondents' ratings, have at least been acquired by formal education

As presented in pie chart of Figure 9, 91\% of the respondents have confirmed the importance of education and preparation for the organization, leadership and human resources management in the engine department. Furthermore, with the option of selecting multiple answers, the second chart in Figure 9 has shown that $100 \%$ of the respondents consider formal education institutions to be the main place of education and preparation for engine department organization, leadership and human resources management. According to the grades obtained, crew employment agencies are the last place where such education and training should be carried out.

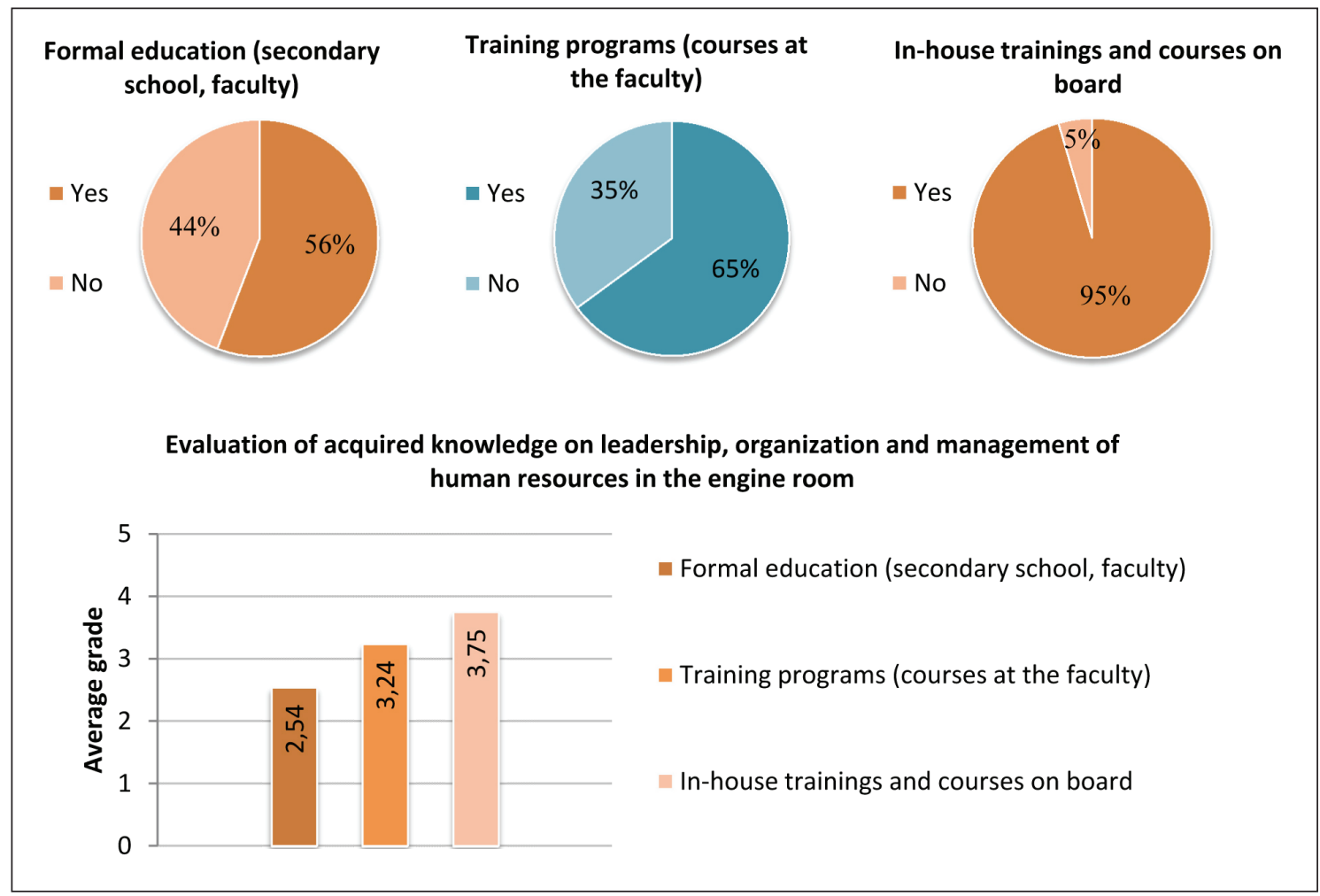

Figure 8 Opinion of the Place of Education and the Evaluation of the Acquired knowledge in Leadership, Organization and Human Resources Management in the Engine room. Source: author

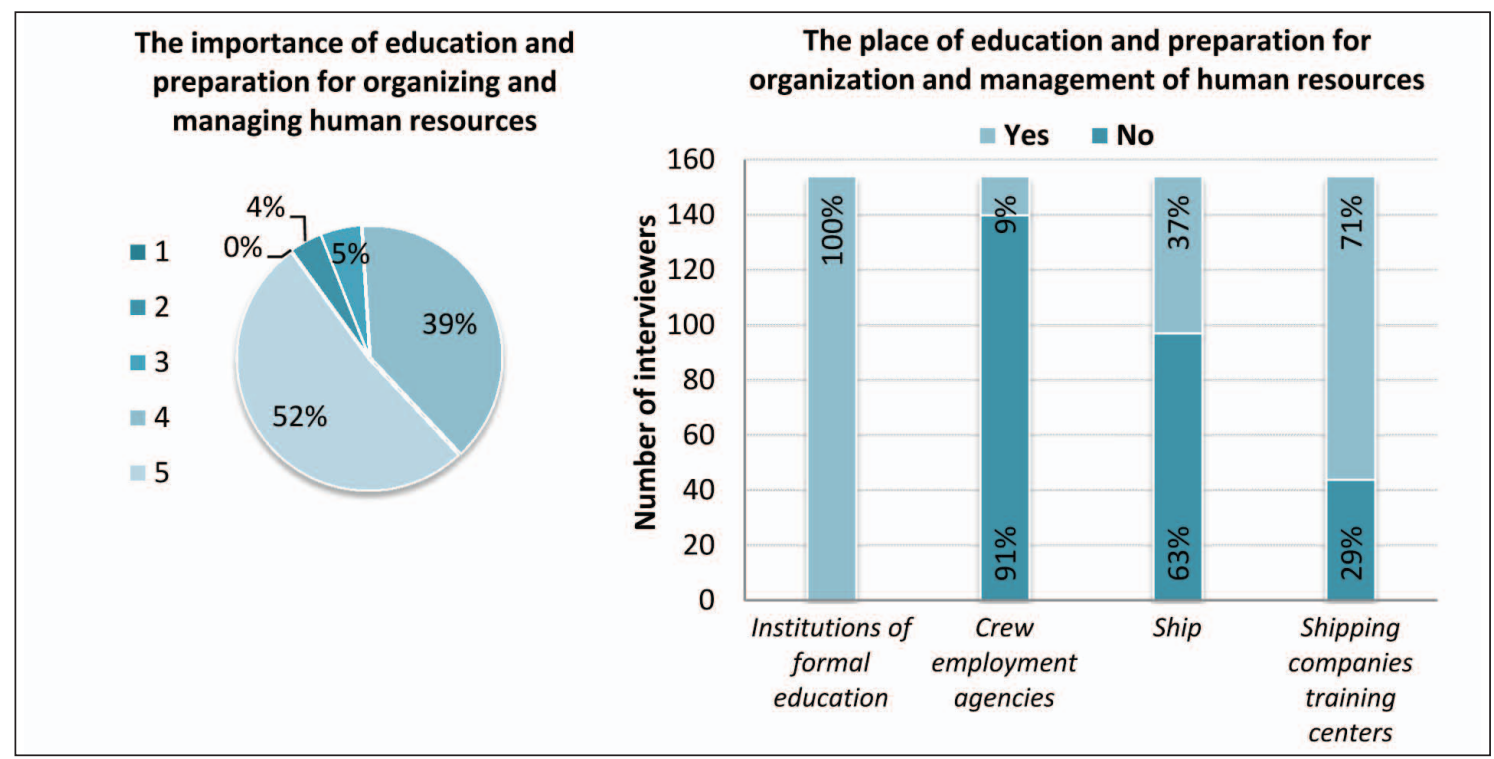

Figure 9 Importance and the most Appropriate Place for Education on Organisation, Leadership and Human Resources Management. Source: author 
Respondents have also highly evaluated the importance of effective preparations for multicultural cooperation and as a primary place for the preparation, and here as well, the formal education institutions are put at the first place, as Figure 10 has shown.

The research survey concludes with a few general questions with answers presented in Figure 11. Interestingly, nearly half of the surveyed seafarers have stated that they do not intend to pursue further with higher education, while $25 \%$ already have some university education degree, which is also in line with the introductory chart regarding the level of education grouped under the general characteristics of the respondents. Slightly over half of the respondents have pointed out that the reason for acquiring higher education is twofold: both, the personal motivation and the requirement or encouragement of their employers. An exceptionally high number of them believe that the quality of higher education in Dubrovnik has contributed to the outstanding reputation of the Dubrovnik seafarers in the maritime labour market. In the foreseeable future, almost half of the surveyed marine engineers still see themselves on board; a third is currently irresolute on this issue, while nearly a fifth of the respondents intend to end their working career ashore.

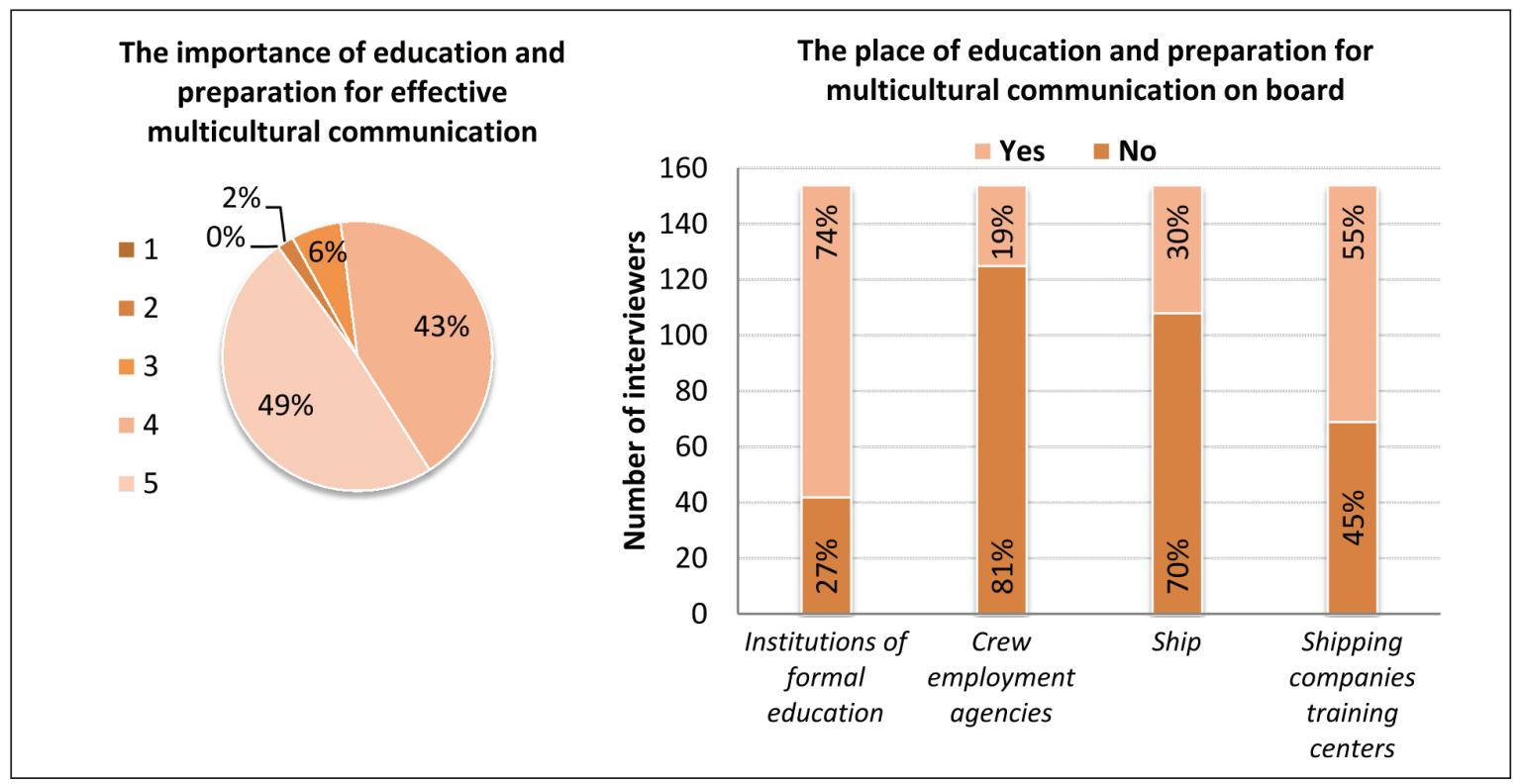

Figure 10 Importance and the most Appropriate Place for Preparation and Training for Multicultural Communication on board. Source: author

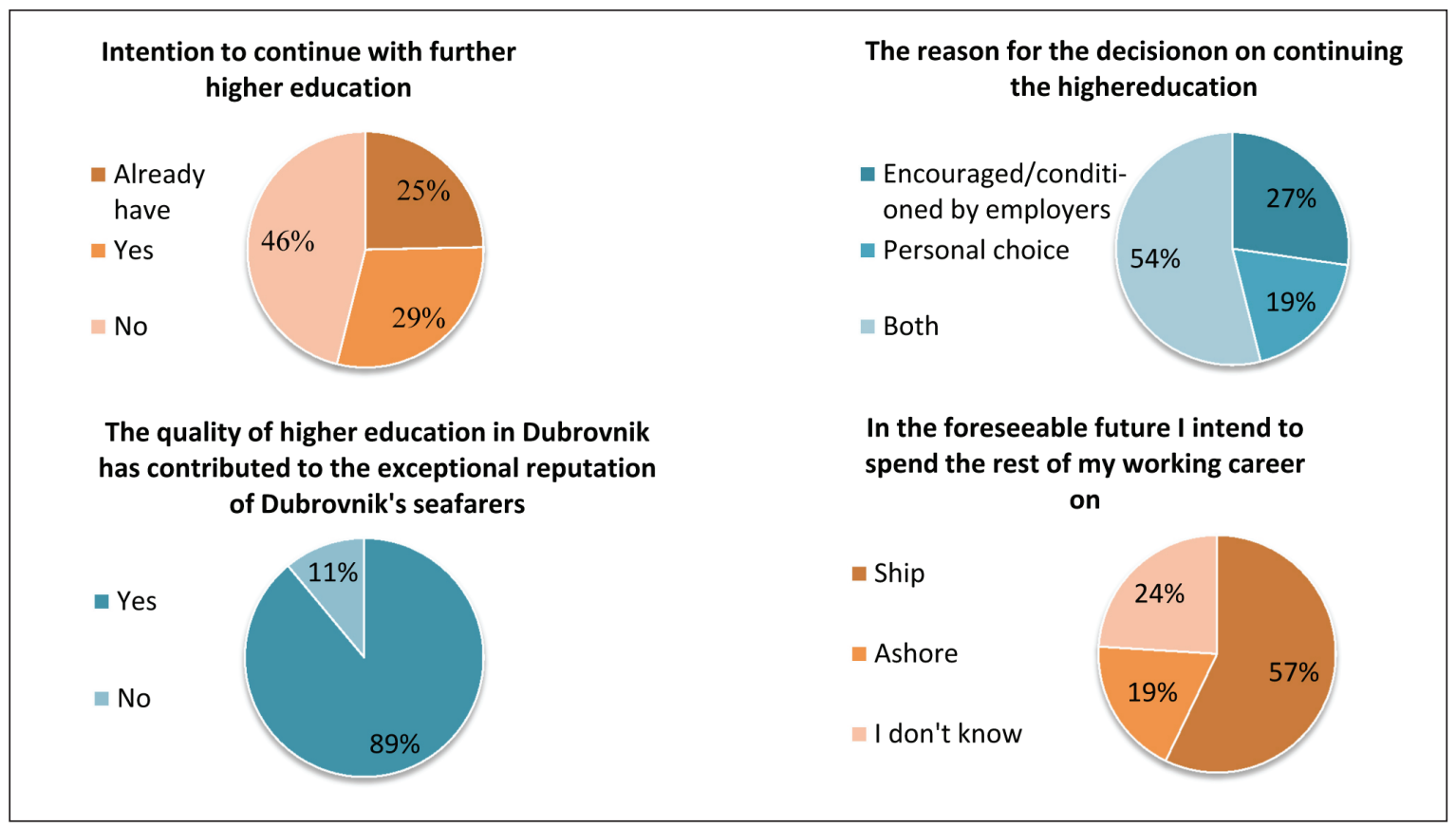

Figure 11 General Questions about the Seafarers' Education and Future Career. Source: author 


\section{Discussion}

The survey results analysis has indicated that the surveyed marine engineers are highly satisfied with their knowledge and skills acquired through higher education, what confirms the main hypothesis of research. It can be concluded that the outcome of the research is sufficiently representative and relevant considering the wide range of respondents' education level, as well as the diversity of seafarers' sea service experience.

It has also been established that seafarers with a higher education level and on senior ship positions point out the general importance of an education more than other colleagues. The importance of English speaking skills, English maritime terminology, IT knowledge, as well as the importance of more intensive implementation of adequate and currently actual contents in educational programmes has been emphasized uppermost.

Since the majority of the participants have completed their maritime education relatively long time ago and since then the maritime higher education system has been improved and modernized in all aspects, it would be interesting to conduct similar research among active seafarers of all maritime professions who have completed their maritime higher education through the latest higher maritime education system and not limited only to the University of Dubrovnik but also within all MHEIs in Croatia or even wider. This would certainly gain better insight and enable more detailed analysis of the current MET from the perspective and the viewpoint of Croatian seafarers for whom this education is intended to and who, through their knowledge and skills are a sort of the unique ambassadors of Croatian MET onto the world maritime labour market.

In further research more attention should have to be put on modern MET trends and technologies which the developed maritime countries increasingly apply and what primarily relates to e-learning, lifelong learning and distance learning technologies. Therefore, the survey questionnaire should be expanded to determine whether and to what extent active seafarers have met with some of the modern methods and learning technologies in the formal, non-formal and informal learning process, i.e. through compulsory or supplementary forms of training and professional courses, either on some of the maritime colleges/universities or shipping companies specialized in training facilities.

The mentioned researches could also be extended to seafarers of other nationalities, which could, from a seafarer's perspective, compare and determine the position and quality of the Croatian MET system with regard to the MET systems in other countries.

\section{Conclusion}

The lack of seafarers, especially officers, has prompted the EU institutions to fund researches and studies through their strategic programmes with aim of popularizing the attractiveness of maritime professions. One of the most important segments of these initiatives also applies to the increasingly intensive improvement and modernization of the MET system in all aspects. Apart from the MET institutions, interest for that is also shared among other maritime industry stakeholders in general which often associate in a number of partnership institutions and various platforms at regional and international level. They join forces and resources in order to achieve certain cognitions which the implementation in the MET systems would ultimately result in highly educated maritime personnel.

For maritime higher education of seafarers in Croatian MHEIs it can be said that it has a respectable international reputation. This is supported by the unquestionable fact that seafarers with Croatian MET background are highly respected in maritime world since they work on globally the most reputable shipping companies in the top ranks. Although, since its existence, MET system at university level has undergone several organization changes and adaptations, particularly institutional, and has successfully "survived" all the challenges they have been facing with. With the final reform, the implementation of the Bologna Declaration and the introduction of a new university model from the academic 2015/2016 year and by equalizing the length of its studies and curricula, Croatia has become part of a unique European higher education model that has brought our students, teachers and seafarers into an equal position with colleagues from other EU countries. However, although the joint efforts of all Croatian MHEIs have formed identical curriculum, certain differences in courses title, teaching hours per week and ECTS credits can presently be observed, which certainly do not support basic ideas of the Bologna reform and international trends in MET.

As one of the challenges faced by some of the MHEIs, while emphasizing Maritime Department of the University of Dubrovnik as the most outstanding, is a lack of adequate teaching staff which can be reflected in the curricula content and quality. In order to enhance existing curricula that would significantly attract more potential students, particularly in graduate studies, it is necessary and important to have an adequate teaching staff. Experienced seafarers with the highest ranks and graduate education who do not wish to work on board ships any longer are ideal candidates for teachers, provided they have enough ambition to continue their education at postgraduate studies. To acquire the knowledge and skills of future seafarers, it is immensely important that their vocational/technical courses teachers are just such experienced people in their profession.

The introduction of an alternative education system through the SEP, which also takes place at MHEIs, met with the part of the maritime profession representatives who considered the existing MET model to be too complex and too long for the purpose of acquiring the highest STCW certificates of competence and that for this purpose the contents conditioned by the STCW Convention are quite sufficient. The SEP attendees who participated in this research have not shown interest in further educa- 
tion through their responses what leads to the conclusion that the most important reason for which they choose this option, whether self-initiated or conditioned/urged by employers, is the possibility of relatively easy and quick fulfilment of the minimum education criteria for acquiring higher STCW certificates of competence. It is also important to emphasize that this option enables them to achieve the necessary education with almost continuous sea service without significant disruption of working contracts.

The conducted research has proved that active marine engineers are satisfied with the quality of MET and offered courses and that education is to the greatest extent adequate for the upcoming work on board and advancement in the maritime profession. The importance of education is emphasized as a priority, and it is evident that seafarers with a higher education degree are more aware of this importance.

Overall, the Croatian MHEIs successfully continue their long-standing tradition and manage to be competitive with similar national, European and international institutions. This is also proved by the abovementioned, relatively high ratings given for the questions of the survey on the quality of university level education, conducted among active and successful marine engineers who completed their studies in Dubrovnik MEHI. In the survey, inadequacy of practical contents has been emphasized as the most significant deficiency of education. It should be taken into account that, at the time of studying, the vast majority of the surveyed seafarers, the Maritime Department of the University of Dubrovnik did not have at disposal, neither a school ship, nor a marine engineering laboratory, a pneumatic-hydraulic laboratory and an engine room simulator, which enables today's students to acquire practical skills. In addition to this, relatively low ratings of IT education and related contents at the time when surveyed seafarers studied should also be noted. At this point it should be signified as well that the IT educational programmes, IT equipment and related facilities at the Maritime Department of the University of Dubrovnik have progressively improved and reached a satisfactory level.

\section{References}

[1] Frančić, V., Zec, D., Rudan, I.: Analysis and Trends of MET System in Croatia - Challenges for the 21st Century, The 12the Annual General Assembly International Association of Maritime University, Green Ships Eco Shipping Clean Seas / Bogumil Laczynski (ur.). - Gdynia Maritime University, 2011. 133-134 (ISBN: 878-83-7421-152-9).

[2] Komadina P., Rudan, I., Frančić, V.: Hrvatsko visoko pomorsko školstvo u svjetlu Bolonjske deklaracije, Pomorski Fakultet u Rijeci, Sveučilište u Rijeci, 2004.
[3] Kotlar V., Klapan V., Gundić A.: Posebni program obrazovanja pomoraca: odgovor obrazovnog sustava na promjene u pomorskoj profesiji, Andragoški glasnik, Vol. 18, br. 1, 2014, str. 47-58.

[4] Marušić, L.: STCW konvencija i Bolonjski proces, Metodički ogledi, 17 (2010) 1-2, 13-22.

[5] Pritchard, B., Zec D., Komadina, P.: On Recent Developments in Maritime Education and Training in Croatia, The 10th European Manning \& Training Conference, Dubrovnik, 23th \& 24th May 2007.

[6] Schröder J-U., Pourzanjani, M., Zade, G.: The Thematic Network on Maritime Education, Training and Mobility of Seafarers (METNET): The Final Outcomes, 4th IAMU General assembly.

[7] Zade G: METNET final report for publication - prepared by Günther Zade with inputs from work package and task leaders, WMU, Malmö, Sweden, november 2003.

[8] Zec, D., Pritchard, B., Komadina, P.: Toward a Global Standard MET System - An Analysis of the Strengths and Weaknesses of present MET Systems, IAMU Journal, June 2000, No. 1, Istanbul: 61-68.

[9] ****: Dvanaesti sveučilišni godišnjak - akademska 2015./16. godina, Sveučilište u Dubrovniku, Dubrovnik, 2016.

[10] ****: Elaborat o sveučilišnom preddiplomskom studijskom programu brodostrojarstvo, Sveučilište u Dubrovniku, Pomorski odjel, veljača 2014.

[11] ****: EP1: Izrada standarda zanimanja i kompetencija; Profil sektora pomorski promet i logistika; Projekt: Razvoj Kvalifikacija i Inovativnih metoda stjecanja Kompetencija u LOgistici i Pomorskom prometu - KIKLOP; Broj ugovora: HR.3.1.15-0029; Referenca projekta: 0029/Sveučilište u Rijeci, Pomorski fakultet u Rijeci/HKO II; Program: Europski socijalni fond (ESF) - Operativni program "Razvoj ljudskih potencijala" 2007.-2013.

[12] ****: Pravilnik o izmjenama i dopunama Pravilnika o zvanjima i svjedodžbama o osposobljenosti pomoraca.

[13] ****: Pravilnik o zvanjima i svjedodžbama o osposobljenosti pomoraca.

[14] ****: Prijedlog programa poslijediplomskog međusveučilišnog znanstvenog doktorskog studija POMORSTVO,Sveučilište u Rijeci, Pomorski fakultet u Rijeci, ožujak 2006.

[15] ****: STCW: A Guide for Seafarers; Taking into account the 2010 Manila amendments, International Transport Workers' Federation, London SE1 1DR, UK.

[16] ****: Strategija pomorskog razvitka i integralne pomorske politike Republike Hrvatske za razdoblje od 2014. do 2020. godine, Zagreb, srpanj 2014.

[17] http://ec.europa.eu/education/policy/higher-education/ bologna-process_hr, veljača 2017.

[18] https://hr.wikipedia.org/wiki/SWOT_analiza, veljača 2017.

[19] http://iamu-edu.org/?page_id=22, veljača 2017.

[20] http://www.c4ff.co.uk/MaritimeEducationDivision. aspx?menu=divisions, veljača 2017 .

[21] http://www.marifuture.org/Projects/Projects.aspx, veljača 2017. 